\title{
Nepalese management education at crossroads: Prospects and constraints
}

\author{
- Dr. Shyam Bahadur Katuwal
}

\section{Introduction}

Higher education is a backbone for an overall development of any nation. It plays vital role not only in raising political and social consciousness but also in increasing the number of skilled workers and raising the level of trained manpower. In this sense too, education enhances productive capacity of human resources and improves individual lives to enrich wider society (Katuwal, 2011). Acceleration of modernization and economic growth also depends on education. At individual level, the benefits are better employment opportunities, higher salaries, better health and quality of life, increase in life expectancy, increase in the tenure of productively and life time earnings, and greater ability to save and invest (Akkari, 2004). These benefit set off various spirals for life expectancy to enable individuals to work more productively over a longer time, further boosting lifetime earnings (Tilak, 1994). Studies in some developed countries have shown strong impact of higher education on economic growth (De Meulemeester and Rochat, 1995). A study done in Nepal has also shown positive relationship between education and income, supporting the presumption that increase in educational attainment leads to increase income level of different social groups (Katuwal, 2011 a). The findings hence suggest that education has economic value and long term impact for the growth and development of any country.

The benefit of education both at individual and national level is known; yet providing education to the general people has been a common challenge all around the world. The challenge is more serious in developing country like Nepal because of 
economic backwardness and low prospective of different economic parameters. The GDP growth rate is estimated to drop to 3.5 percent with decreasing ratio of gross national saving to GDP, increasing rate of inflation and deficit balance of payment. It is a fact that more than one-fourth of people are still living below absolute poverty line (the figure is high in the estimation of international agencies) with increased income disparity of 0.46 point Gini coefficient though their per capita GDP was said to have increased to $\$ 556$ in 2009/10 (MoF, 2011).

In this situation, when the government has to look after all the sectors of development, tertiary education is often far from the highest priority (Hauptman and Salmi, 2006, p.3).

\section{Objectives}

The basic objective of this study was to identify the prospects and constraints of management education and to suggest ways for managing the constraints, especially with the focus on TU.

\section{Methods and data source}

The source of data for the study was secondary. Because of the variation and paucity of data, only the data from Ministry of Finance, GoN was used to calculate the flow of students in different academic programs of the universities. The students studying in higher secondary schools are not covered considering them as a part of school education.

Similarly, information was obtained from articles in journals, bulletins and reports of the concerned organization. The information/data collected from different sources were analyzed by using descriptive and inferential statistics (like absolute number, percentage, average, trend analysis, t-test and simple correlation) to reach the conclusion of the study. 


\section{Research questions and hypothesis}

The study attempts to answer the following questions:

- How is the scenario of management education in Nepal?

- How is the popularity and prospect of management education in Nepal?

- What is the growth trend of management education in Nepal?

- Does management education have prospect for growth?

- What is the share of different universities in management education in Nepal?

- How popular is the management education of TU?

- What are the constraints of management education in Nepal?

Based on the research questions, the study has formulated a null hypothesis that is 'enrollment in TU and the enrollment in other universities are not independent'.

\section{Discussion}

\section{Scenario of management education}

Due to lack of resources and hesitation of government to invest in education sector, universities have been obliged to launch programs that are self-sustainable, popular and marketable in national and international level. Faculty of Management in TU has also been offering different programs in management through its constituent and affiliated campuses throughout the country ${ }^{1}$. Besides TU, management education is being offered by Kathmandu University (KU), Purbanchal University (PU), and Pokhara University (PoKU). Foreign-based universities and institutions have also entered in the market.

\footnotetext{
${ }^{1}$ The programs include 5 courses at Bachelor level, 1 PGD course, 5 courses at Master level, 2 courses at MPhil level and Doctorate Program.
} 


\section{Popularity and prospect of management education}

In spite of many constraints, management education has remained a major area of attraction for Nepalese students. The number of students in management education has been increasing every year from the inception of commerce education in Nepal by Tri-Chandra College in 1954 AD. The growing importance of management education can be read in Acharya's (2009) study report:

Currently, more than 376 campuses (26 constituents and 350 affiliated) are present throughout the country...Management education is second in terms of students' enrolment... With this trend, management education will undoubtedly hold top-position in all respects in near future. The multidisciplinary approach professed by management education has led to the concrete realization of the importance of it by people opting different professional fields (pp.91-92).

The data in Table 1 presents a comparative picture of students enrolled in technical field (including pure science) and management for last 10 years in Nepal.

$\underline{\text { Table } 1}$

Students' enrollment by faculty, universities and years *

\begin{tabular}{|c|c|c|c|c|c|c|c|c|c|c|}
\hline \multirow{2}{*}{ FY } & \multicolumn{2}{|c|}{ TU } & \multicolumn{2}{|c|}{$\mathrm{KU}$} & \multicolumn{2}{|c|}{$\mathrm{PU}$} & \multicolumn{2}{|c|}{$\mathrm{PoKU}$} & \multicolumn{2}{|c|}{ Total } \\
\hline & Tech & $\mathrm{Mgmt}$ & Tech & Mgmt & Tech & Mgmt & Tech & Mgmt & Tech & Mgmt \\
\hline '00/01 & 19058 & 39374 & 1319 & 127 & 585 & 229 & 899 & 733 & 21861 & 40463 \\
\hline $01 / 02$ & 19264 & 37490 & 1529 & 177 & 705 & 315 & 1640 & 1256 & 23138 & 39238 \\
\hline${ }^{\circ} 02 / 03$ & 18413 & 37210 & 1470 & 120 & 1180 & 538 & 2307 & 1751 & 23370 & 39619 \\
\hline $03 / 04$ & 18741 & 31341 & 1993 & 120 & na & $\mathrm{na}$ & 2481 & 2064 & 23215 & 33525 \\
\hline $04 / 05$ & 18891 & 36578 & 2032 & 158 & 6184 & 1218 & 2406 & 2159 & 29513 & 40113 \\
\hline${ }^{\circ} 05 / 06$ & 20823 & 41803 & 4652 & 782 & 938 & 2412 & 2516 & 2974 & 28929 & 47971 \\
\hline $06 / 07$ & 22502 & 33311 & 4964 & 1127 & 5116 & 3684 & 2353 & 2690 & 34935 & 40812 \\
\hline $07 / 08$ & 23433 & 44854 & 5705 & 1305 & 6234 & 4026 & 1727 & 3722 & 37099 & 53907 \\
\hline${ }^{\circ} 08 / 09$ & 25878 & 39194 & 6273 & 1355 & 6932 & 4078 & 3416 & 4127 & 42499 & 48754 \\
\hline $09 / 10$ & 24030 & 45941 & 6069 & 1287 & 7620 & 4979 & 5027 & 8030 & 42746 & 60237 \\
\hline Total & 211033 & 387096 & 36006 & 6558 & 35494 & 21479 & 24772 & 29506 & 307305 & 444639 \\
\hline
\end{tabular}

Source: MOF (2011). *New intake only 
The analysis of data in Table 1 shows that TU has been serving large number of students in management education. The role of TU, vis-à-vis the number of management education offering universities, is also outstanding. It alone shares 86.86 percents (357 out of 411) of the total, Table 2.11 (UGC, 2011).

The statistics of students enrolled in different universities, despite fluctuation in some years, exhibits that management education is the first choice of Nepalese students in the last 10 years. The consolidation, in Acharya's words, presents increasing share of management students in higher education proving itself as a burgeoning discipline in the academic arena (2009, p.94). Indeed, management education has enormous prospects in Nepal due to the demand of management graduates in emerging sectors of economy like tourism, water resource management, ever growing nature of business organization and entry of multinational companies, and service sectors (Koirala, 2005).

\section{Trend of management education}

A comparative analysis of students' enrollment as shown in Figure 1 demonstrates a steady growth in technical field. The number in management education, which is progressive but fluctuating, points at greater thrust of students towards management after technical education. The figure also indicates that the number of students in technical and management education will be moreover the same after 24 years if the present trend of growth continues.

Almost all the universities, their constituents and affiliated campuses have been offering various level of management education. The reasons for students' attraction to management education, among others, are easy access, low cost, high demand in local and global labor market and high remuneration in comparison to investment during graduation. 


\section{Figure 1}

Flow of students in management and technical education

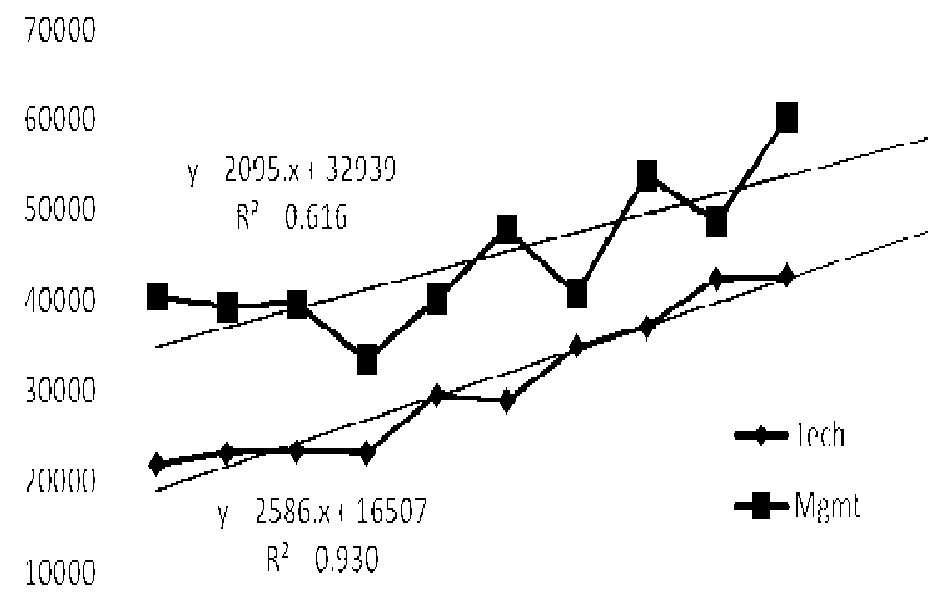

0

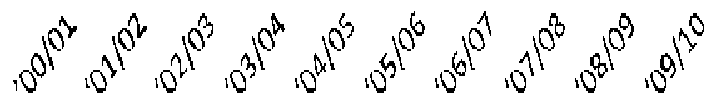

\section{Share of universities in management education}

When we analyze university-wise strength of intake, we observe the share of TU largest of all; it has fulfilled, in an average, $87 \%$ demand. However, as new universities have emerged with varieties of management programs, TU has been gradually losing the share of students. The figure shows share of TU dropping from 97.31 in $2000 / 01$ to 76.27 in $2009 / 10$. It can be reasoned that the decline is the effect of other universities' establishment; nonetheless, it should not be forgotten that the trend undeniably indicates deterioration in the attraction of students towards TU. 
Table 2

Share of universities in management education

\begin{tabular}{|c|c|c|c|c|c|c|c|c|}
\hline FY & \multicolumn{2}{|c|}{ TU } & \multicolumn{2}{c|}{ KU } & \multicolumn{2}{c|}{ PU } & \multicolumn{2}{c|}{ PoKU } \\
\cline { 2 - 9 } & Share & Growth & Share & Growth & Share & Growth & Share & Growth \\
\hline '00/01 & 97.31 & 100 & 0.31 & 100 & 0.57 & 100 & 1.81 & 100 \\
\hline${ }^{\prime} 01 / 02$ & 95.55 & 95.22 & 0.45 & 139.37 & 0.80 & 137.55 & 3.20 & 171.35 \\
\hline${ }^{\prime} 02 / 03$ & 93.92 & 99.25 & 0.30 & 67.80 & 1.36 & 170.79 & 4.42 & 139.41 \\
\hline${ }^{\prime} 03 / 04$ & 93.49 & 84.23 & 0.36 & 100.00 & 0.00 & na & 6.16 & 117.88 \\
\hline${ }^{\prime} 04 / 05$ & 91.19 & 116.71 & 0.39 & 131.67 & 3.04 & na & 5.38 & 104.60 \\
\hline${ }^{\prime} 05 / 06$ & 87.14 & 114.28 & 1.63 & 494.94 & 5.03 & 198.03 & 6.20 & 137.75 \\
\hline$' 06 / 07$ & 81.62 & 79.69 & 2.76 & 144.12 & 9.03 & 152.74 & 6.59 & 90.45 \\
\hline${ }^{\prime} 07 / 08$ & 83.21 & 134.65 & 2.42 & 115.79 & 7.47 & 109.28 & 6.90 & 138.36 \\
\hline${ }^{\prime} 08 / 09$ & 80.39 & 87.38 & 2.78 & 103.83 & 8.36 & 101.29 & 8.46 & 110.88 \\
\hline$' 09 / 10$ & 76.27 & 117.21 & 2.14 & 94.98 & 8.27 & 122.09 & 13.33 & 194.57 \\
\hline Average & 87.06 & 102.86 & 1.47 & 149.25 & 4.83 & 136.47 & 6.64 & 130.53 \\
\hline
\end{tabular}

Source: Table 1

\section{Attraction of students towards TU and other universities}

In spite of increase in students' enrollment in Nepal every year, TU has been losing its share in both technical and management field. The perfect negative correlation $(r=-1)$ between the share of TU and other universities (Table 3) justifies that the enrolment in $\mathrm{TU}$ and in other universities have negative association. It shows that as much as the enrollment of students in TU increases, it decreases enrollment in other universities and vice versa. The perfect negative correlation value reinforces the null hypothesis indicating that the students have more attraction towards other universities than TU in general and management education in particular. It also indicates the tendency of students shifting from TU to other universities. 
Table 3

Students' enrollment in TU and other universities

\begin{tabular}{|c|c|c|c|c|}
\hline \multirow{2}{*}{ FY } & \multicolumn{2}{|c|}{ Share in management } & \multicolumn{2}{c|}{ Share in total } \\
\cline { 2 - 5 } & TU & $\begin{array}{c}\text { Other } \\
\text { Universities }\end{array}$ & TU & $\begin{array}{c}\text { Other } \\
\text { Universities }\end{array}$ \\
\hline${ }^{\prime} 00 / 01$ & 0.97 & 0.03 & 0.94 & 0.06 \\
\hline${ }^{\prime} 01 / 02$ & 0.96 & 0.04 & 0.91 & 0.09 \\
\hline${ }^{\prime} 02 / 03$ & 0.94 & 0.06 & 0.88 & 0.12 \\
\hline${ }^{\prime} 03 / 04$ & 0.93 & 0.07 & 0.88 & 0.12 \\
\hline$' 04 / 05$ & 0.91 & 0.09 & 0.80 & 0.20 \\
\hline${ }^{\prime} 05 / 06$ & 0.87 & 0.13 & 0.81 & 0.19 \\
\hline$' 06 / 07$ & 0.82 & 0.18 & 0.74 & 0.26 \\
\hline$' 07 / 08$ & 0.83 & 0.17 & 0.75 & 0.25 \\
\hline$' 08 / 09$ & 0.80 & 0.20 & 0.71 & 0.29 \\
\hline$' 09 / 10$ & 0.76 & 0.24 & 0.68 & 0.32 \\
\hline Correlation & \multicolumn{3}{|c|}{} \\
\hline
\end{tabular}

Source: Table 1. * Perfect negative correlation

The shift of students to other universities may be due to the lack of different facilities in TU like compliance of academic calendar, assurance of sending abroad, twining with foreign degree, market demand courses and so on. If TU aims to attract students towards its academic programs, it has to focus on these issues.

\section{Constraints of management education}

As in other sectors, universities in Nepal have been facing financial, political and policy related problems. No concrete policy has been framed on higher education so far and in every political movement/activity, schools and colleges are badly affected (RIDA, 2011). Even though many educational institutions have been established, the trend of students going aboard every year for higher education has not lessened; instead it has increased exponentially. 
Figure 2

Students going to foreign countries for higher education

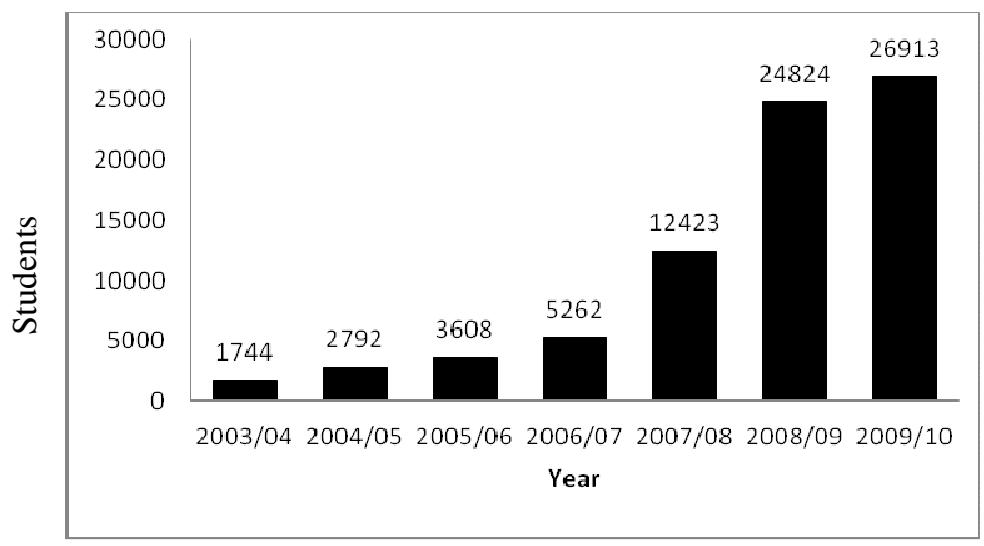

Source: Gorkhapatra, (2009: July 17) and MoE (2010 a \& 2011)

Figure 2 shows that the number of students going to foreign countries for higher education (based on no objection letter issued) is growing every year. It indicates that the attraction of students towards foreign education has not decreased despite an increase in the number of educational institutions year by year (MoE, various years).

The statistics of 26913 , i.e., the number of no-objection letter issued from Nepal Government in 2009/10 to grant permission to study in foreign counties in self finance basis in different disciplines (MoE, 2011), indicates that a large number of students go abroad for foreign education. The record does not include students who have gone to India as they do not require such letter. Thus, the addition of students who have gone to India to the number of students who have gone aboard with no objection letter would reach the figure to very high number. And, in this statistics, management education occupies a remarkable share. According to the record, hospitality management occupies the highest position. Among the noobjection letters issued for students in 2008/09, the number of students in the field of hospitality management was 3000 
followed by business management (1600 students) and 1379 students in accounting sector (Gorkhapatra, 2009: July 17).

The noncompliance of academic calendar, untwining with foreign degree, political instability, glamour of outside world and foreign degree, assurance of job during and after the study and similar other reasons have stood as the cause of attraction to education in foreign countries. Some of those reasons along with quality and cost factor have been responsible to make the universities competitive within the country also. If the planners of higher education and the authority of universities in Nepal pay due attention to the reasons of the outflow of students, it can provide avenue to reshape university education system in terms of quality, economy of cost and other issues.

As there is cut down of foreign support in education, GoN has no alternative to curtailing expenditure in education. The reduction may cause adverse impact on scholarship scheme, grants on books and course materials, development of physical and educational materials required for quality education. In such a situation, it is obvious that private sectors would enter in education sector with heavy fee structure in the name of quality education, causing financial burden to the guardians. Due to unaffordable fee structure, education will be out of reach for poor people. Consequently, education status of the poor remains always lower than that of rich people in the country with counterproductive effect in development process.

\section{Quality vis-à-vis financial constraints}

Education sector is one of the areas where private sector generally does not exhibit their interest for investment. And, in such sector, there is no option to government, but to invest. In reality, however, the government seems to be reluctant to invest even when the government resource has been the main source of funding and the demand for higher education is increasing. There is steady decline in proportion of Government Education Budget for higher education in Nepal (CEDA, 2007: 41 and 
RIDA, 2011). The other alternative source would be foreign aids and grants. But, due to financial crisis in the developed countries, they have also been curtailing their support to the developing countries. The annual growth of foreign assistance in education has been found to decrease after 2008/09 and it has reached in negative growth of 10.6 percent in 2010/ 11(Katuwal, 2011).

Now, the panorama of management education sector (which is true in other cases as well) is like this: GoN is not in position for more financing and there is ever-growing interest of students towards management education. The situation has created congenial environment for the private sector to establish new educational institution and for the government to leave out the responsibility of investing in education. In this circumstance, there is no other alternative to involve private sector to fill the gap.

Signs of private sectors' involvement have been visible through an increased number of private business schools running courses in business management (Kraft and Vodopoviec, 2003). More than ten times higher figure of affiliated colleges than the constituent college of Nepalese universities is a clear indication. The observance of the data published by the Ministry of Education, GoN clearly specifies more than 10 time greater number of affiliated colleges than the constituent college of Nepalese Universities ( MoE, 2011).

Although management education is said to be the first cost recovery and dynamic program of TU (Acharya, 2009), limitation in the use of latest teaching technologies and equipment, and the use of properly managed well-equipped library are creating problem to make management education qualitative. To be specific about TU, management education is in the verge of quality collapse due to financial constraints related to physical infrastructure, use of modern pedagogy, faculty development, research and library use. In addition, huge number of students in a situation of limited physical 
infrastructure and small number of quality teachers (trained faculty members) has created problems in maintaining academic standard in undergraduate program specially BBS level in TU (Koirala, 2005).

\section{Findings and implications}

The data in general indicates growing attraction of students towards management education in comparison to technical education; however, the fluctuating growth of management intake shows anomaly of attraction towards this field. The steady growth in technical sector in contrast to fluctuating growth in management sector hint that students either quit their study or go aboard for study. The second argument is partially true as per the analysis of data of students going aboard for study with no-objection letter (MoE, 2010, 2011). Such kind of fluctuation is heavier for TU. This is also clear indication that students desiring to study management education within the country have shifted from TU to other universities. It demands TU to identify the root cause of this situation and make an appropriate policy in right time. Otherwise, management program of the university may fall into a serious problem of existence.

In the country's move towards market economy especially after liberalized policy of 1990s, there is a high demand to produce professionally qualified mangers. Such a scope has triggered even the private sector to establish business schools in different corners of the country. Nepalese educationists with the support of entrepreneurs have also established business schools over the years. As a consequence, management schools have been forced in competitive mode and uplift their quality. However, it has not been enough to properly address the students' craze to join foreign universities for quality education. A large number of young students are still going abroad or India with the huge flight of national capital. In addition, many foreign business schools and universities, through their wing in Nepal or agencies, have fetched a large number of students. 
To rectify, there is a need of adequate investment in physical infrastructure, faculty development and research oriented curriculam. If moves are made to manage existing problems, management education will certainly produce human resources of high-level necessary in administration and management of business organizations. For it, governmental, non-governmental and international organizations can contribute. The industry (employer) can also contribute to solve many problems of their organizations by joining hands with the academicians in university especially in the process of human resource acquisition, training and development, research activities, case studies, and professional pursuits.

The attraction of Nepalese students towards foreign countries and proliferation of foreign university affiliated colleges in Nepal may create propels to Nepalese management colleges. Specifically, the universities, which could not maintain the cripple of growth by introducing appropriate policy and strategies to attract students, initiate foreign-based management education programs, may suffer from the problem of existence itself. Thus, every university and college in the field of management education should frame out the courses of international standard, set provision for credit transfer, train teachers for modern pedagogy by introducing modern technology of teaching and learning.

To enhance quality education in university level, the University Grants Commission (UGC), which is an authority to finance and certify accreditation and quality assurance of universities, may play an active role to enhance quality of university education in general and the quality of management education in specific. UGC can contribute by developing criteria for quality management education and providing accreditation of grades to the colleges of management education. As a member of the World Federation of University Grants Commissions, the UGC Nepal can issue global accreditation of management education. Such a provision may compel colleges to improve their quality of education. Consequently, outflow of foreign 
going students can be checked and outflow of foreign currencies in the name education can be reserved in the country.

As there is financial crisis to run business schools smoothly as state funded university like Tribhuvan University, other institutions have to adopt alternative strategies so as to raise the fund for the sustainability of the program. In this situation, the business schools may strengthen their financial position by providing research and management consultancy to the business house, governmental and non-governmental organization with fees and remuneration. Likewise, management colleges or institutes can offer management-development programs to corporate body in private and public sector. Business schools can run the satellite education programs, part-time (flexi time) classes for busy persons and management and research consultancy to fully utilize the potentials of management schools and the faculty therein. The business schools can attract the students from neighboring countries through the charge of handsome subscription by developing and imparting quality management education.

As afford to quality management education is tough for general people, government needs to introduce loan scheme to the needy students against the condition of reimbursing the loan amount after their employment. Other alternatives such as compulsory work in the public sector for a specified period can be opted.

Through the above mentioned measures, business schools can fully utilize their capacity, fill the gap of financial shortage and make management education easily affordable and thereby contribute for the prosperity of the country. 


\section{References}

Acharya, G.P. (2009). Management eduication in Nepal: Milieu and future track. In Tribhuvan University Golden Jubilee Souvenir 2009 (pp. 90-95). Kathmandu: Tribhuvan University.

Akkari, A (2004). Education in the Middle East and North Africa: The current situation and future challenges. International Educational Journal, 5, (2), 144-153.

CEDA (2007), Financing the higher education in Nepal, A study report submitted by the Centre for Economic Development and Administration (CEDA), Kathmandu to South Asia Network of Economic Research Institutes (SANEI), Islamabad.

De Meulemeester, Jean-Luc, and Denis, R. (1995). A causality analysis of the link between higher education and economic delopment. Economics of Education Review, 14 (4), 251-261.

Gorkhaptra Dainik, July 17, 2009.

Hauptman, A., and Salmi, J. (2006). Innovations in Tertiary education financing: A comparative evaluation of allocation mechanisms. Washington, D.C: The World Bank.

Katuwal, S. B (2011), Global Financial crisis and higher education in Nepal. International Journal of Business Management, Economics and Information Technology, 3 (1), 39-45.

Katuwal, S. B. (2011 a). Socio-economic inequality: An implication for managing labour market. International Journal of Business Policy and Economics, 4 (1), 5164.

Koirala, P. (2005). Vision and mission of management education in Nepal. Tribhuvan University Journal, XXV (1), 27-32.

Kraft, E., and Vodopoviec, M. (2003). The new kids on the block: The entry of private business schools in transition economies. Education Economics, 11, 239257. 
MoE. (2010). A glance of educational information. Kathmandu:

Ministry of Education, Nepal Government.

MoE. (2010 a). Nepal educations in figures 2010: At-a-glance.

Kathmandu: Ministry of Education, Nepal Government.

MoE. (2011). Nepal educations in figures 2011: At-a-glance.

Kathmandu: Ministry of Education, Nepal Government.

MoE. (Various Years). Nepal education in figures, Kathmadu.

Ministry of Education, Nepal Government.

MoF. (2011), Economic Survey Fiscal Year 2010/11.

Kathmandu: Ministry of Finance, Nepal Government.

MoF. (Various Years). Red Books, Kathmandu: Ministry of

Finance, Nepal Government.

RIDA (2011). Higher education in Nepal. The Educationist, 1.

Kathmandu: Research Inputs and Development Action (RIDA).

Tilak, J. B. G. (1994). Education for development in Asia. New Delhi: Sage publications.

UGC. (2011). Education management information system: Report on higher education 2008/09. Bhaktapur: University Grants Commission (UGC), Nepal.

(The author is grateful to Prof. Dr. Govinda Prasad Acharya for his comments and suggestions.)

The author is a Reader at Faculty of Management, Post Graduate Campus, Tribhuvan University, Biratnagar, Nepal. Email: skatuwal@bcn.com.np/shyam-katuwal@yahoo.com 